\title{
THE RELATIONSHIPS OF STUDENTS ADMISSION PROCESS AND ACADEMIC ACHIEVEMENT
}

\author{
Asty Amalia Nurhadi, ${ }^{1 *}$, Shelly Salmah ${ }^{3}$, Nasrum Massi ${ }^{4}$, Firdaus Kasim ${ }^{5}$ \\ ${ }^{1}$ Department of Medical Education, Faculty of Medicine Hasanuddin University, Makassar - INDONESIA \\ ${ }^{2}$ Department of Anatomy, Faculty of Medicine Hasanuddin University, Makassar - INDONESIA \\ ${ }^{3}$ Department of Histology, Faculty of Medicine Hasanuddin University, Makassar - INDONESIA \\ ${ }^{4}$ Department of Microbiology, Faculty of Medicine Hasanuddin University, Makassar - INDONESIA \\ ${ }^{5}$ Department of Public and Community Health, Faculty of Medicine Hasanuddin University, Makassar - INDONESIA
}

Submitted: 23 May 2018; Final Revision from Author: 01 Jan 2020; Accepted: 06 Mar 2020

\begin{abstract}
Background: The selection process in medical schools should be able to identify individuals that most probably will successfully complete their education. In Faculty of Medicine Hasanuddin University (FMHU) the selection processes are Seleksi Nasional Masuk Perguruan Tinggi Negeri), SBMPTN (Seleksi Bersama Masuk Perguruan Tinggi Negeri), JNS (Jalur Non Subsidi) and International students. Looking at the various selection methods in FMHU, this study aimed to see how each selection method related with students' academic achievement.
\end{abstract}

Methods: This study compared academic achievement in two semesters at three academic admission students (2014, 2015 and 2016), for four admission processes. The data consist of 308 students from batch of 2014, 308 students from batch of 2015, and 320 students from batch of 2016. The analysis was conducted in descriptive analysis, One Way ANOVA, and followed by Post-hoc Bonferroni Test.

Results: There was significant difference of students GPA for each type of admission. The highest academic achievement was obtained by students from International and SNMPTN admission while the lowest academic achievement was obtained by students from SBMPTN and JNS.

Conclusion: Students from International and SNMPTN admission had the highest academic achievement compared to SBMPTN and JNS. This study showed that there should be an evaluation of the assessment used in SBMPTN and to continue the use of SNMPTN as one of the main admission route at FMHU.

Keywords: student selection, academic achievement, predictive validity

\section{ABSTRAK}

Latar belakang: Proses seleksi mahasiswa kedokteran seharusnya dapat mengidentifikasi individu-individu yang akan mampu menyelesaikan pendidikan. Proses seleksi mahasiswa di Fakultas Kedokteran Universitas Hasanuddin (FKUH) terdiri atas SNMPTN (Seleksi Nasional Masuk Perguruan Tinggi Negeri), SBMPTN (Seleksi Bersama Masuk Perguruan Tinggi Negeri), JNS (Jalur Non Subsidi), dan Jalur Internasional. Penelitian ini bertujuan untuk melihat hubungan antara masing-masing jalur seleksi dengan prestasi akademik mahasiswa.

Metode: Penelitian ini membandingkan prestasi akademik (IPK) dua semester mahasiswa angkatan 2014, 2015 and 2016, untuk empat jalur seleksi. Data terdiri atas 308 mahasiswa angkatan 2014, 308 mahasiswa angkatan 2015, dan

*corresponding author, contact: nurhadiastyamalia@gmail.com 
320 mahasiswa angkatan 2016. Analisis data dilakukan melalui analisis deskriptif,, One Way ANOVA yang diikuti oleh Post-hoc Bonferroni Test.

Hasil: Terdapat perbedaan signifikan IPK mahasiswa untuk setiap jenis jalur seleksi. IPK tertinggi diperoleh mahasiswa dari jalur Internasional and SNMPTN, sedangkan IPK terendah diperoleh mahasiswa dari jalur SBMPTN dan JNS.

Kesimpulan: Mahasiswa dari jalur internasional dan SNMPTN memiliki prestasi akademik yang paling baik dibandingkan jalur SBMPTN dan JNS. Penelitian ini menunjukkan perlunya dilakukan evaluasi terhadap proses assessment pada jalur SBMPTN dan memertahankan jalur masuk SNMPTN sebagai salah satu jalur seleksi utama FKUH.

Kata kunci: seleksi mahasiswa, capaian akademik, validitas prediktif

\section{PRACTICE POINTS}

- SNMPTN and international students had higher GPAs, it could be recommended that this type of admission process should be prioritized.

- There should be evaluation of type assessments used in SBMPTN, as one of the admission processes for medical faculty.

- There should be further evaluation of factors that affected students' academic achievement.

\section{INTRODUCTION}

Medical institutions are obliged to educate students with goal of producing competent medical doctor in providing primary health service. ${ }^{1}$ Biggs expressed that the output of an educational system is related to the input and the educational process. ${ }^{2}$ While according to National Standard of Medical Doctor Education, each Medical Institution should have Students Selection Policy that aligns with the principles of relevancy, transparency, accountable, and academic and social responsibility. ${ }^{1}$ Therefore, selection process is an essential aspect that can influence the outcome of educational process in medical faculty.

In most medical schools, the selection process determines the quality of the medical students. ${ }^{3}$ This process is intended to identify individuals that most probably will successfully complete their education. ${ }^{3}$ Therefore, to guarantee the quality of students, the admission must be able to have predictive validity toward their academic achievements. ${ }^{3}$

There are several studies that assessed the relationship of selection process with students' academic achievements. ${ }^{4 \cdot 6}$ However, those studies are mostly comparing one type of selection scores toward academic achievement, and none of the studies compared all student selection process toward academic achievement. There is also knowledge gap related with the topic in Indonesian context.

There are only a few studies done in Indonesian context, and none of the studies compared all student selection process toward academic achievement., ${ }^{7,8}$

Faculty of Medicine Hasanuddin University (FMHU) is an A accredited medical faculty located in Eastern Part of Indonesia. Recently, there are four student selection processes in FMHU. SNMPTN is a national selection process that is based on high school academic achievement. SBMPTN is the university selection based on paper/computer-based test which includes Academic Potential Test with Science and Technology Test. JNS (Independent) is the nonsubsidized route for students with financial ability whose scores on SBMPTN were not optimum to be accepted through SBMPTN. International route is selection route for International students who were selected using previous academic achievement (high school or diploma).

Mostly, the primary selection process of medical schools is a high academic achievement in their previous study. ${ }^{3}$ However, in FMHU there are four 
processes in selecting medical students. Looking at the various admission methods for medical students of FMHU, this study aimed to see how each selection method related to students' academic achievement.

This study examined students two semesters academic achievement for three academic year students (2014, 2015, and 2016). This study also provided comparison of academic achievement for each selection process for three years in a row.

\section{METHODS}

This study was a quantitative research with crosssectional analytic design that compared the types of selection process with students' academic achievement at FMHU in September and November 2017. The sampling method in this study was a total sampling, which included the whole students for academic year 2014, 2015, and 2016. The dependent variable in this research was two semesters students' academic achievement (GPA). The independent variables were the students' admission processes
(SBMPTN, SNMPTN, JNS, and International).

The data of this study was secondary data obtained from the academic division for students' grades for two semesters. The data on students' admission was obtained from the students' affair division. Data analysis of this study was done using SPSS ver 18.0. Descriptive analysis was conducted to see the distribution of students for each selection type and mean, median, and standard deviation of students' GPA for each selection type. Bivariate analysis was administered to analyze the relationships of students' admission process and academic achievement using One Way ANOVA which is followed by Post-hoc of Bonferroni Test.

\section{RESULTS AND DISCUSSION}

Data of this study are obtained from 936 students (308 students of 2014 batch, 308 students of 2015 batch, and 320 students of 2016 batch). The distribution of students based on their type of admission process is presented in Table 1.

Table 1. Distribution of Students Based on Their Type of Admission

\begin{tabular}{lcccccc}
\multirow{2}{*}{ Type of Admission } & \multicolumn{2}{c}{2014} & \multicolumn{2}{c}{2015} & \multicolumn{2}{c}{2016} \\
\cline { 2 - 7 } & $\mathrm{N}$ & $\%$ & $\mathrm{~N}$ & $\%$ & $\mathrm{~N}$ & $\%$ \\
SNMPTN & 118 & 38.3 & 118 & 38.3 & 93 & 29.1 \\
SBMPTN & 76 & 24.7 & 92 & 29.9 & 78 & 24.4 \\
JNS & 65 & 21.1 & 65 & 21.1 & 115 & 35.9 \\
International & 49 & 15.9 & 33 & 10.7 & 34 & 10.6 \\
Total & 308 & 100 & 308 & 100 & 320 & 100
\end{tabular}

The highest students' proportion for batch 2014 and 2015 (Table 1) was from SNMPTN, followed by SBMPTN, JNS, and International. While, for batch 2016 the highest proportion was from SNMPTN and followed by JNS, SBMPTN, and International.
One-way ANOVA Test showed that there was significant difference of students' GPA for each type of admission $(p<0.05)$. The Levene's homogeinity test revealed that the data was homogen $(p<0.05)$, therefore the post hoc analysis was done using Bonferroni Test. The results of Bonferroni Test are presented in Table 2. 
Table 2. Bonferroni Tests Result

\begin{tabular}{clcc} 
Batch & \multicolumn{1}{c}{ Comparison } & Mean Difference & p Value \\
\multirow{2}{*}{2014} & SNMPTN-SBMPTN & 0.32955 & 0.001 \\
& SNMPTN-JNS & 0.72951 & $<0.001$ \\
& SNMPTN-International & -0.06713 & 1.000 \\
\hline \multirow{2}{*}{2015} & SNMPTN-SBMPTN & & $<0.001$ \\
& SNMPTN-JNS & .39204 & 0.032 \\
& SNMPTN-International & -.15974 & 1.000 \\
\hline \multirow{2}{*}{2016} & SNMPTN-SBMPTN & 1.41199 & $<0.001$ \\
& SNMPTN-JNS & .87287 & $<.001$ \\
& SNMPTN-International & .57819 & 0.007 \\
\hline
\end{tabular}

Bonferroni test (Table 2) for batch of 2014 showed that the highest mean of GPA was achieved by students from International admission process, followed by SNMPTN, SBMPTN, and JNS. For 2015 batch, the highest mean GPA was achieved by International admission, followed by SNMPTN, JNS, and SBMPTN. For batch 2016, the highest mean GPA was achieved by SNMPTN, followed by International, JNS, and SBMPTN.

Data analysis for batch 2014, 2015, and 2016, showed that highest academic achievement was obtained by students from International and SNMPTN admission. International and SNMPTN admissions were route of selections that used previous academic achievement. This finding was also echoed by other studies. $^{4 \cdot 7,9}$ It seems that students who had a good previous school academic achievement might have a better academic foundation and learning habit that could contribute to their academic achievement in medical faculty.

This study then showed that since SNMPTN students had high academic achievement, this type of admission should be the main students' admission for FMHU. On the other hand, the lowest academic achievement was obtained by students from SNMPTN and JNS. Interestingly, for batch of 2016, JNS students whose selection results were lower than SBMPTN had higher GPA. This showed that SBMPTN could not predict students' academic achievement. This might be cause of the items on SBMPTN were generally applied for all faculty and not specifically designed for medical faculty.

Mostly in USA and Europe, Medical Institutions applied specific aptitude test which was designed specifically for selecting medical students. However, the predictive validity of these tests was still not evident in most of the studies. ${ }^{10}$ Some institutions combined aptitude test with interview. Conversely, reports on the predictive validity of this method are varies. Foley $\&$ Hijazi ${ }^{11}$ found that MMI was a stronger predictor for academic achievement of dental students while Goho \& Balckman ${ }^{12}$ and Sladek et al. ${ }^{13}$ reported that there was no significant relationship between interview and academic achievement.

In Indonesian context, there was limited report on relationship of admission test with academic achievement. Only one study by Permatasari, Prabandari, \& Kristina, ${ }^{7}$ who reported that the academic test (was specifically designed for Faculty of Medicine Universitas Swadaya Guning JatiUnswagati), had predictive validity toward medical students' academic achievement.

In FMHU context, this study has produced recommendation related with admission scheme proportion. The current admission trend of FMHU, as can be seen at Table 1 , shows that there is a tendency of reducing proportion of SNMPTN scheme and 
increasing proportion for JNS. However, this study has shown that students with SNMPTN route has higher academic achievement, therefore FMHU should consider prioritizing SNMPTN scheme as admission route and increase the proportion.

\section{CONCLUSION}

This study found that students from International and SNMPTN admission had the highest academic achievement compared to SBMPTN and JNS. However, there was a tendency to reduce students' intake from SNMPTN and increase students' intake from JNS. As students from SNMPTN had higher academic achievement compared to SBMPTN and JNS, FMHU should consider prioritizing SNMPTN as admission route and evaluate the assessment use in SBMPTN.

\section{ACKNOWLEDGEMENT}

This study was funded by Institute of Research and Community Service Hasanuddin University 2017.

\section{COMPETING INTERESTS}

The authors declare that there are no competing interests related to the study.

\section{ABBREVIATIONS LIST}

$\begin{array}{ll}\text { FMHU } & \text { : Faculty of Medicine Hasanuddin } \\ & \text { University } \\ \text { SNMPTN } \quad \text { Seleksi Nasional Masuk Perguruan } & \\ & \text { Tinggi Negeri } \\ \text { SBMPTN } \quad \text { Seleksi Bersama Masuk Perguruan } & \\ & \text { Tinggi Negeri } \\ \text { JNS } & \text { : Jalur Non Subsidi }\end{array}$

\section{AUTHORS' CONTRIBUTION}

Asty Amalia Nurhadi - developing research proposal, collecting data, data analysis, and publication manuscript; Shelly Salmah - developing research proposal and collecting data; Nasrum Massi developing research proposal and collecting data; Firdaus Kasim - data analysis and publication manuscript

\section{REFERENCES}

1. Indonesia KK. Standar pendidikan profesi dokter. Jakarta: Konsil Kedokteran Indonesia. 2006. http://www.kki.go.id/assets/data/ arsip/Final_SPPDI,_21_Maret_2013.pdf

2. Biggs J, Kember D, Leung DY. The revised twol factor study process questionnaire: RISPQ $22 \mathrm{~F}$. British journal of educational psychology. 2001 Mar 1;71(1):133-49. http://www.johnbiggs. com.au/pdf/ex_2factor_spq.pdf

3. Patterson F, Ferguson E, Knight AL. Selection into medical education and training. Understanding Medical Education: Evidence, Theory and Practice. 2014:401-20.

4. Mercer A, Puddey IB. Admission selection criteria as predictors of outcomes in an undergraduate medical course: A prospective study. Medical teacher. 2011 Dec 1;33(12):9971004. http://www.tandfonline.com/doi/abs/1 0.3109/0142159X.2011.577123

5. Gardner SP, Roberts-Thomson KF. Predicting High Achievers in the University of Adelaide, Australia, Bachelor of Oral Health Program, 2002-09. Journal of dental education. 2012 Dec 1;76(12):1646-56. http://www.jdentaled.org/ content/76/12/1646.full

6. Lucieer SM, Stegers-Jager KM, Rikers RM, Themmen AP. Non-cognitive selected students do not outperform lottery-admitted students in the pre-clinical stage of medical school. Advances in health sciences education. 2016 Mar 1;21(1):51-61. https://www.ncbi.nlm.nih. gov/pmc/articles/PMC4749643/

7. Permatasari TO, Prabandari YS, Kristina TN. Tes Seleksi Mahasiswa Baru Sebagai Prediktor Terhadap Prestasi AkademikTes Seleksi Mahasiswa Baru Sebagai Prediktor Terhadap Prestasi Akademik. Tunas Medika Jurnal Kedokteran \& Kesehatan. 2016 Jun 21;3(1).

8. Ashaeryanto A, Kristina TN, Hadianto T. The Relationships of The types of Entry Selection of Students with their Learning Motivation, Learning Strategies, and Learning Achievement. Jurnal Pendidikan Kedokteran 
Indonesia; The Indonesian Journal of Medical Education.;6(1):1-0.

9. Lynch CD, McConnell RJ, Hannigan A. Dental school admissions in Ireland: can current selection criteria predict success? European Journal of Dental Education. 2006 May 1;10(2):73-9. http://onlinelibrary.wiley. com/doi/10.1111/j.1600-0579.2006.00398.x/ abstract

10. Tiffin PA, Mwandigha LM, Paton LW, Hesselgreaves H, McLachlan JC, Finn GM, Kasim AS. Predictive validity of the UKCAT for medical school undergraduate performance: a national prospective cohort study. BMC Med Educ. 2016 Sep 17;14(1):140. https://www.ncbi. nlm.nih.gov/pmc/articles/PMC5026770/
11. Foley JI, Hijazi K. The admissions process in a graduate-entry dental school: can we predict academic performance? British dental journal. 2013 Jan 26;214(2): E4-. https://www.nature. com/articles/sj.bdj.2013.56

12. Sladek RM, Bond MJ, Frost LK, Prior KN. Predicting success in medical school: a longitudinal study of common Australian student selection tools. BMC medical education. 2016 Jul 22;16(1):187. https://link.springer. com/article/10.1186/s12909-016-0692-3

13. Goho J, Blackman A. The effectiveness of academic admission interviews: an exploratory meta-analysis. Med Teach, 2006;28(4), pp.335340. http://www.tandfonline.com/doi/s/10.10 $80 / 01421590600603418$ ? src $=$ recsys $\&$ journalCo de $=$ imte 20 